\title{
The Idea of a "Greater Europe” in Russian Foreign Policy: Past and Present
}

\author{
Anatoly V. Tsvyk ${ }^{a}$, Konstantin P. Kurylevb \\ aUnaffiliated researcher, Moscow, Russia; a.tsvyk91@mail.ru \\ bRUDN University, 10, Miklukho-Maklaya St., Moscow, 117198, Russia, \\ Email: kurylev-kp@rudn.ru
}

\section{Идея «Большой Европы» во внешней политике России: история и современность}

\author{
А.В. Цвыка, К.П. Курылевь \\ аНеаффилированный исследователь, г. Москва, Россия; a.tsvyk91@mail.ru \\ bРоссийский университет дружбы народов, 117198, Россия, Москва, \\ ул. Миклухо-Маклая, 6, Email: kurylev-kp@rudn.ru
}

\begin{abstract}
This article examines the notion of a "Greater Europe" in Russian foreign policy from the 1990s to the present. The idea developed as the Russian government sought to establish its national and civilizational identy in the wake of the USSR's dissolution. At the turn of the $21^{\text {st }}$ century, Moscow embraced the idea of a rapprochement with the rest of Europe. Pursuing the notion of "Greater Europe," to create a single continental economic, political and cultural space, became a major diplomatic objective as it developed a strategic partnership with the European Union. However, in more recent years its outlook on the world has changed. Furthermore, after relations with Brussels deteriorated in the wake of the Ukrainian crisis and the latter's imposition of sanctions has also affected Russian foreign policy. This article considers the emergence and evolution of the idea of a "Greater Europe", and examines possible ways to realize this ambition. It argues that a EAEU-EU "combination" could become a basis for implementing this concept. However, any potential rapprochement can only be possible when the political barriers the EU established in its relations with Russia and the EAEU are removed.

Keywords: Russia, foreign policy, Greater Europe, Eurasian Economic Union, European Union

For citation: Tsvyk, Anatoly V., and Kurylev, Konstantin P. "The idea of a "Greater Europe" in Russian Foreign Policy: Past and Present." RUDN Journal of Russian History 19, no. 2 (May 2020): 438-447. https://doi.org/10.22363/2312-8674-2020-19-2-438-447

Acknowledgements and Funding: This research was supported by the Russian Science Foundation. The scientific project № 19-18-00165.

Аннотация: Развитие российского государства исторически сопровождалось поиском национально-цивилизационной идентичности, что проецировалось на его внешнюю политику. В конце XX - начале XXI в. Россия обратилась к идее сближения с европейскими странами и выдвинула концепцию «Большой Европы» как проект создания единого общеевропейского экономического, политического гуманитарного пространства. Реализация проекта «Большой Европы» стала одним из главных направлений российской внешней политики конца XX - начала XXI в. Однако с начала 2000-х гг. международная обстановка значительно изменилась. После событий 2014 г. на Украине и последующих санкций со стороны ЕС отношения между Россией и Евросоюзом оказались в состоянии глубокого кризиса, что значительно осложнило осуществление идеи о единой и неделимой «Большой Европе». В данной статье авторы прослеживают историю возникновения и развития идеи «Большой Европы», выявляют проблемы ее реализации в новом
\end{abstract}

(C) Tsvyk A.V., Kurylev K.P., 2020

(c) (i) This work is licensed under a Creative Commons Attribution 4.0 International License https://creativecommons.org/licenses/by/4.0/ 
формате взаимодействия между Евразийским экономическим союзом и Европейским союзом. Авторы приходят к выводу, что эффективное взаимодействие между евразийской и европейской интеграциями может придать новый импульс идее «Большой Европы» только в случае преодоления политического барьера в отношениях между ЕС и Россией.

Ключевые слова: Россия, внешняя политика, Большая Европа, Евразийский экономический союз, Европейский союз

Для цитирования: Цвык А.В., Курылев К.П. Идея «Большой Европы» во внешней политике России: история и современность // Вестник Российского университета дружбы народов. Серия: История России. 2020. Т. 19. № 2. С. 438-447. https://doi.org/10.22363/2312-8674-2020-19-2-438-447

Благодарности и финансирование: Исследование выполнено за счет гранта Российского научного фонда (проект № 19-18-00165).

\section{Introduction}

As it evolved, the Russian state sought to establish its national and civilizational identity, an endeavor that was reflected in its foreign policy. At the turn of the $21^{\text {st }}$ century, Moscow embraced the idea of a rapprochement with the rest of Europe and advocated a "Greater Europe" to create a single pan-European economic, political and cultural space. As a result, implementing a Greater Europe became one of it main foreign policy goals, as it developed a strategic partnership with the European Union. However, since the early 2000s, the global environment has changed dramatically. After the events of 2014 in Ukraine, relations between Russia and the EU entered into a deep crisis, which made it much more difficult to establish a single and undivided Greater Europe. At the same time, Moscow's diplomatic priorities also changed as it developed Eurasian orientation and integrating its states in this space now became a major priority. As a result, it now sought closer ties not only with the EU, but also with China, which also has integration initiatives in Eurasia.

In his speech in 2015 at the $20^{\text {th }}$ annual conference of the Baltic Forum, "The U.S., the European Union (EU) and Russia - the New Reality," Russia's former Foreign Minister Igor Ivanov acknowledged the failure of the Greater Europe project. As he put it, "Russia is no longer the eastern flank of the abortive Greater Europe and is becoming the western flank of the emerging Greater Eurasia". Nevetheless the question remains relevant: Does the rise of "Greater Eurasia" mean the end of a "Greater Europe"?

This article traces the emergence and evolution of the idea of a Greater Europe. It will go on to analyze possible ways of implementing it according to the example of interaction between the Eurasian Economic Union (EAEU) and the EU, and concludes by considering the prospects for a Greater Europe.

\section{The History of the Idea of "Greater Europe"}

In 1959, French President Charles de Gaulle proclaimed: "Europe - from the Atlantic Ocean to the Ural Mountains - it is Europe that will determine the future of the world"2. Scholars still debate the meaning of his phrase. Not a proponent of Atlanticism, the French leader went on to use the expression "Europe from the Atlantic Ocean to the Urals" on multiple occasions and in different contexts, to effect a rapprochement between France and Germany in promoting European integration, and establish a dialog with the USSR. At a meeting with Soviet Ambassador S.A. Vinogradov, De Gaulle said: "Time will come when we will be building Europe together with the Soviet Union"3.

1 I. Ivanov, "Zakat bolshoi Evropy," Russian International Affairs Council, accessed November 4, 2019 , https://russiancouncil.ru/en/analytics-and-comments/analytics/zakat-bolshoy-evropy/.

${ }^{2}$ E.Iu. Il'in, "The concept of Greater Europe from Lisbon to Vladivostok: problems and perspectives," MGIMO Review of International Relations 4, no. 2 (2015): 77-85.

${ }^{3}$ A. Oganesyan, "Evropa: ot Lissabona do Vladivostoka, accessed December 4, 2019, http://www.geopolitics.ru/ 2012/12/evropa-ot-lissabona-do-vladivostoka-2/. 
As he expanded the geopolitical contours of single Europe all the way to the Urals, including the European part of the USSR, the president was probably the first European politician to consider continental unity in the context of closer ties with Moscow. In effect, he hoped to enlarge the boundaries of the European Economic Community's "Smaller Europe." However, his endeavor to tie Europe's leading nations more closely with Russia culturally, economically, politically, as well as in defence, has deep roots in history.

Over the centuries, Russia relationship with the West has been seen in the context of its own national identity. It was a question that occupied the minds of Russia's elite beginning with Peter the Great's reforms in the early $18^{\text {th }}$ century, when the empire was seen as backward compared to Europe. The quest to become an equal of the West was an important element of its transformation into a European great power. And in taking the European path of modernization championed by the "Westernizers," Russia sought closer ties with the continent's other powers. ${ }^{4}$

Western scholars have seen Russia's relations with the rest of Europe in different ways. Sir Halford Mackinder, the most prominent representative of the Anglo-Saxon school of geopolitics, introduced the notion of the "Heartland" in his landmark article of 1904, "The Geographic Pivot of the History." This was his term for northwestern Eurasia, rich in natural resources and geographically inaccessible to Great Britain or any other maritime nation. Sir Halford noted that the Heartland had strongly influenced European events throughout history. In his opinion, Europe was the home of modern civilization. However, the Heartland, controlled by Russia (or the USSR) was a force that made a direct impact on the continent. Therefore, joining it with Russia might create the most powerful combination in the world, thereby eclipsing the British Empire.

Subsequently, the German school of geopolitics saw the Soviet Union as a potential ally to oppose the Anglo-Saxon maritime powers, i.e. the U.K. and the U.S. In the 1920's and 30's, Karl Haushofer, one of its most prominent advocates, advocated a Berlin Moscow - Tokyo continental bloc. More recently, the neo-fascist Belgian politician JeanFrançois Thiriart proposed a "Euro-Soviet Empire from Vladivostok to Dublin," to liberate the continent from the American "thalassocracy" (rule by the sea). ${ }^{6}$

During the Cold War, when Western - above all British and American - strategists saw the Soviet Heartland as their main ideological rival, any serious attempt to create a European political and military common space with the USSR was virtually impossible. ${ }^{7}$ Nevertheless, some European statesmen, most notably De Gaulle, as well as Soviet leaders, held out hopes for such a combination. According to I. Timofeev,

Europe was divided into two military and political camps. But their equivalence, as well as the internal consolidation and stability of virtually all players made it possible to have common rules of the game. ${ }^{8}$

In 1985, the signing of the final act of the Conference on Security and Co-operation (CSCE) in Europe, or Helsinki Accords, which defined the underlying principles of Soviet cooperation with the West, was an important step towards a Greater Europe.

${ }^{4}$ R. Taras, Russian Identity in International Relations: Images, Perceptions, Misperceptions (London: Routledge, 2013), 305. $421-437$.

${ }^{5}$ H.J. Mackinder, "The Geographical Pivot of History," The Geographical Journal 23, no. 4 (1904):

${ }^{6}$ Edouard Rix, "Jean Thiriart, the Machiavelli of United Europe, accessed November 20, 2019, https:// www.academia.edu/12121122/Jean_Thiriart the_Machiavelli_of_United_Europe.

${ }^{7}$ C. Crouch, D. Marquand, Towards Greater Europe? A Continent without an Iron Curtain (Oxford: Blackwell Publishers, 1992), accessed 12 December, 2019, http://books.google.com/books?id=MzlYIgAACAAJ\&dq= $\% 22$ Greater+Europe $\% 22 \&$ as_brr $=0$.

${ }^{8}$ I. Timofeev, "An unbalanced Europe and a new order in the OSCE area," Paper of "Valdai" International Discussion Club, accessed November 20, 2019, http://ru.valdaiclub.com/files/ 23949/. 
During the Perestroika era of the 1980's, Soviet leader Mikhail Gorbachev raised the idea of a rapprochement with the West through a "Common European Home." During his visits to France in 1985 and Czechoslovakia two years later, he explained that his initiative was to help overcome the Cold War by eliminating the military and political hostility between the continent's socialist and capitalist systems. ${ }^{10}$ However, according to I. Maksimychev,

weaknesses of an updated political system of the USSR/Russia were effectively used by the West to impose its own pattern of a 'New World Order' on the global community, a pattern that did not take into account Russia's security needs. ${ }^{11}$

The Charter of Paris for a New Europe adopted at a 1990 CSCE summit in Paris "set forth guidelines for realization of a community of free and democratic States from Vancouver to Vladivostok" - a Greater Europe, which were reaffirmed by the $1992 \mathrm{Hel}-$ sinki Declaration of the CSCE. But those documents were not binding.

The Soviet Union and, afterwards, Russia, diligently abided by all the clauses of the resolutions, without heeding any possible domestic political repercussions; other parties carefully selected what suited them and what did not. It is perfectly obvious that a true 'Greater Europe' was not among their priorities, ${ }^{12}$

I. Maksimychev justly notes.

The Soviet leadership's controversial actions in domestic and foreign policy, followed by the disintegration of the USSR in 1991 and subsequent collapse of a bipolar system of international relations did not bring about the Common European Home that Gorbachev so ardently desired. On the contrary, notes A.V. Vinogradov,

the West, by inertia, perceived its victory in Europe as a victory on global scale, a triumph in the $\square$ old War, as it haughtily ignored not only the defeated Russia but the rising East $^{13}$.

Kuznetsov adds,

The 1990s were essentially a time when an EU-centric model of 'Greater Europe' was beginning to dominate. It is not by chance that the term 'Greater Europe' in Western academic papers was increasingly substituted with 'Wider Europe' (etymologically close to 'Expanded Europe,' which implies the presence of a nucleus of some sort). ${ }^{14}$

The Wider Europe included the former members of the Eastern bloc, which were to be integrated with the European Union.

In 1994, the EU signed an Agreement on Partnership and Cooperation with Russia. While it was a step ahead in bettering relations between the two parties, as F. Lukianov noted, Russia was not going to be integrated with the EU. However, the idea of "strategic partnership" became the conceptual basis of relations between Russia and Union during the entire post-Soviet period. ${ }^{15}$

It was becoming increasingly evident that the approach in Brussels to building a Greater Europe remained vastly different from Russia's. The former's policy with regard to Eastern Europe was to predicate its relations on the EU's dominance. For instance, in March 2003

9 T. Hopf, Understandings of Russian Foreign Policy (Pennsylvania: Pennsylvania State University Press, 1999), 205.

${ }^{10}$ I.M. Busygina, Osnovy Bol'shoi Evropy (Moscow: Spetskniga Publ., 2014), 31-62.

${ }^{11}$ Ibid., 115.

12 Ibid., 115.

13 A.V. Vinogradov, "Russia in Eurasia: between China and the West. Identity, Ideology and Geopolitics," Outlines of global transformations: politics, economics, law 12, no. 2 (2019): 228-246.

${ }^{14}$ A. Kuznetsov, "Rethinking the concept of Greater Europe due to the Ukrainian crisis," International Affairs, no. 12 (2014): 6-17.

${ }^{15}$ F. Lukianov, "Nebol'shaya Evropa," Rossiiskaia gazeta, accessed November 3, 2019, https://rg.ru/ 2016/08/16/fedor-lukianov-evrosoiuz-vpal-v-konceptualnyj-stupor.htm. 
the European Commission released a report titled "Wider Europe - Neighborhood: A New Framework for Relations with our Eastern and Southern Neighbors," which unveiled a new European neighborhood policy and emphasized the EU's importance in strengthening ties with neighboring countries.

The primary objective of this neighborhood policy was establishing "special relations" with CIS nations to prevent a regional union under Russia's auspices. As M. Lagutina notes, the EU de facto started knowingly to exclude Russia from participating in its neighborhood policy, despite the latter's central geopolitical role in the post-Soviet space. In declaring its goal to be creating a Europe "without dividing lines," Brussels was actually producing new divisions between Russia and other CIS countries. Moscow, in turn, sought to keep its influence in the region by developing its own integration initiatives and projects. At the same time, as N. Arbatova notes, "The space to the east of the EU is treated as a single unit, though Russia is seen to occupy a special position because its resources are important for Europe as a whole." ${ }^{\prime 6}$ R. Sakwa agrees: "on a range of structural and ideological issues Russia and Europe were increasingly mutual dependent, as in the energy sector, as well as in security matters"17.

However, Atlanticism was growing stronger, and NATO continued its eastward expansion. It was not only gradually eliminating the idea of Russia as a guarantor of common European security but also suggested a policy of more active military and political confrontation with Moscow. By contrast, the idea of building a Greater Europe of Russia and the EU largely determined the former's foreign policy in the early $21^{\text {st }}$ century.

In 2005, at a Russia-EU summit in Moscow, the parties adopted "roadmaps" towards building a common economic space, as well as common spaces of freedom, security, justice, external security, scientific research, and education. Going forward, implementing these roadmaps was linked to the idea of building a common economic space from Lisbon to Vladivostok. ${ }^{18}$ Speaking at a top-level meeting within the framework the summit's framework, Russian President Vladimir Putin referred to a Greater Europe, which, in his view, had been under construction since the Berlin Wall had come down. ${ }^{19}$

Many scholars see the "Partnership for Modernization" initiative proposed in 2009 at a Russia-EU summit as a way to strengthen their strategic partnership and create a common economic space. The partnership's priorities included encouraging investment in key sectors driving growth and innovation; enhancing and deepening bilateral trade and economic relations; promoting small and medium-sized enterprises; sponsoring harmonization of technical regulations and standards, as well strictly enforcing intellectual property rights, among other. ${ }^{20}$

However, during the next decade Russia's foreign policy priorities shifted away from the West towards Eurasian integration ${ }^{21}$. The political conflict between Russia and the EU that resulted from the Ukrainian crisis of 2014 and the latter's subsequent sanctions put significant obstacles in the way of a of a Greater Europe. One result was the Treaty on

\footnotetext{
${ }^{16}$ N. Arbatova, "Cooperation or Integration? Russia and Greater Europe," Osteuropa 53, no. 9 (2003): $1492-1500$.

${ }^{17}$ R. Sakwa, "Looking for a Greater Europe: From Mutual Dependence to an International Regime," Communist and Post-Communist Studies 45, no. 3-4 (2012): 315-325.

${ }^{18}$ V.V. Putin, "Po itogam sammita Rossiya - ES utverzhdeny ,dorozhnye karty” chetyrekh obshchikh prostranstv," accessed November 25, 2019, http://kremlin.ru/events/president/news/33331.

${ }^{19}$ V.V. Putin "Vstupitel'noe slovo na vstreche na vysshem urovne Rossiya - Evropeiskii soyuz," accessed 7 November, 2019, http://www.kremlin.ru/events/president/transcripts/22966.

20 "Initsiativa Rossiya-ES‘Partnerstvo dlya modernizatsii," accessed November 3, 2019, http://eurussiacentre.ru/wp-content/sklad/2009/10/EURC_review_XV_RUS.pdf.

${ }^{21}$ A.V. Tsvyk, "'Greater Europe' or 'Greater Eurasia'? In Search of New Ideas for the Eurasian integration, RUDN Journal of Sociology, 18, no. 2 (2018): 262-270.
} 
the Eurasian Economic Union, which took effect in 2015. A. Lukin notes that "Russia began to demonstrate its desire to act as a "collector" of the single geopolitical space of the Eurasian continent.",22

\section{The Eurasian Economic Union and the European Union: The End or New Possibilities for the Greater Europe?}

This new diplomatic orientation eastwards did not mean abandoning the idea of a Greater Europe, but the EAEU's emergence has nevertheless changed it. In a 2011 article in the Moscow daily Izvestia, Vladimir Putin revisited the notion. As he saw it, the future EAEU was meant to be an integral part of Greater Europe united by shared values of freedom, democracy, and market laws. The Russian president emphasized that the dialogue with the EU was to be carried out on behalf of the Customs Union (later the EAEU), not Russia alone. ${ }^{23} \mathrm{~A}$ few weeks later, the paper published a piece by Belarus' President Alexander Lukashenko discussing the prospects for Eurasian integration. Also advocating an undivided Greater Europe, he introduced the term "integration of integrations" into the discourse. ${ }^{24}$

Since its creation, the EAEU has attempted to open a dialogue with the European Union. In October 2015, the Eurasian Economic Commission (EAEC) approached the European Commission to establish official contacts and begin discussions to create a common economic space. ${ }^{25}$ However, the official reply from Brussels in November was to Moscow rather than the EAEC (and, consequently, to the EAEU). Jean-Claude Juncker, who then headed the Commission, did reply that he supported developing relations between the EU and the EAEU, noting that he had instructed his staff to consider possible areas of cooperation with the latter. At the same time, he pointed out that any decisions would have to be adopted by a consensus of all EU member nations and must be linked to the Minsk Accords on Ukraine. Russia reacted by expressing its doubts about tying any collaboration between the two unions and settling the Ukrainian imbroglio, since, in its view, implementing the Minsk Accords largely depended on Kiev.

N. Kondrateva argues that the EU's inability to pursue a better relationship with the EAEU is quite understandable. First, there are a number of formerly socialist East European countries among its members, some of whom are hostile to Russia. At the same time, the post-Soviet space is an area of special interest for the EU's Eastern Partnership initiative ${ }^{26}$ and establishing EAEU exacerbated their rivalry. As has been pointed out, the European neighborhood policy and the Eastern Partnership are only feasible in the absence of any alternatives to European integration. Indeed, in pursuing the former, EU officials disregard the EAEU and are unwilling to consider mechanisms for developing relations between the two entities. ${ }^{27}$

Moreover, according to Russian scholars, the EU often prefers to deal with the EAEU's members on a bilateral basis, such as its "Eastern Partnership" involving Belarus and Armenia. For example, on the back of an Eastern Eastern Partnership summit in Brussels in

${ }^{22}$ A. Lukin, D. Novikov, "From Greater Europe to Greater Eurasia: What Brings the World a Fundamental Geopolitical Shift," Vostok. Afro-Aziatskie obshchestva: istoriia i sovremennost, no. 5 (2018): 60-76.

${ }^{23}$ V. Putin "A new integration project for Eurasia-the future that is emerging today," Izvestia, accessed November 6, 2019, https://iz.ru/news/52761.

${ }^{24}$ A.O. Lukashenko, "About the destiny of our integration," Izvestia, accessed November 8, 2019, https://iz.ru/news/504081.

25 "The Eurasian Economic Union proposes to start a dialogue on the creation of a common economic space," TASS, accessed November 7, 2019, http://tass.ru/ekonomika/2380019. (2018): 62 .

${ }^{26}$ N. Kondrateva, "EU-EAEU Relations: Features of the Present Stage," Sovremennaya Evropa, no. 3

${ }^{27}$ Ibid., 64. 
late November 2017, the EU and Armenia signed a Comprehensive and Enhanced Partnership Agreement, which includes provisions on trade and economic cooperation, liberalization of the visa regime, etc. ${ }^{28}$ At the same time, work is under way for the EU to enter into a similar agreement with Belarus.

In both cases, the initiative to deepen bilateral cooperation came from the EU, which, according to Irina Gurova, was motivated by a desire to compete with Russia over closer links with former Soviet republics. ${ }^{29} \mathrm{M}$. Entin suggests that Brussels hopes to profit from controversies within the EAEU, adding that its members must work towards establishing common gound and be wary of setting up any free trade zone with the EU. ${ }^{30}$

As a result, integrating the EAEU with the EU remains on the drawing board, despite its promise of building a common economic, political and cultural space within the framework of Greater Europe. One obstacle is the fact that politics tend to take precedence over economic interests. As N. Zaslavskaia observed, political and conceptual differences, competing geopolitical priorities, clashing values, as well as diverging conceptions of possible interaction impede cooperation between the two groups. ${ }^{31}$

According to A. Gromyko, the EAEU and the EU walk a fine line between co-existence and confrontation. The idea of common space from Lisbon to Vladivostok remains an important goal for the future, because the EU needs it no less than the EAEU. ${ }^{32}$ In considering the relationship between the two institutions, A. Bazhan discerns three elements: Military and political confrontation; co-existence, regardless of that confrontation; and there is cooperation since they interact economically through trade and investment. ${ }^{33}$

The model of the EU's domestic market has become a benchmark for identifying priorities of the Eurasian economic model, in Kondrateva's opinion. She explains that during a short period, the EAEU adopted many institutional and legal elements of the European model. As a result, from the very start, similarities between the way the two unions have developed have encouraged their congruence in the future. Indeed, they share many mutual interests. First, the EU could play a pivotal role promoting technological development and digitalization in the EAEU's member nations. Second, EAEU members could provide energy security to the EU. Most important, their interaction could be the foundation of a new security system, one that is Eurasian rather than Atlantic, without U.S. involvement.

\section{Conclusion}

At the turn of the $21^{\text {st }}$ century, better relations with European governments became a top priority for Russia's leaders. To realise this ambition, they suggested the idea of a Greater Europe to build a common pan-European economic, political and cultural space. The concept of single, undivided Greater Europe with the USSR/Russia had deep historical roots. However, during the Cold War closer ties with Western Europe were virtually

28 "Evrosoyuz i Armeniya podpisali soglashenie o partnerstve," Deutsche Welle, accessed November 29, 2019, http://www.dw.com/ru/evrosoyuz-i-armeniya-podpisali-soglashenie-o-partnerstve/a-41524625.

${ }^{29}$ I. Gurova, "Eastern Partnership: Trade Integration of the EU Target Countries," Mirovaya ekonomika i mezhdunarodnye otnosheniya 62, no. 3 (2018): 86-97.

30 "Evraziiskii ekonomicheskii soyuz i Evrosoyuz: sotrudnichestvo, sosushchestvovanie ili konfrontatsiya," accessed October 30, 2019, https://eurasia.expert/evraziyskiy-ekonomicheskiy-soyuz-i-evrosoyuzsotrudnichestvo- sosushchestvovanie-ili-konfrontatsiya.

${ }^{31}$ N.G. Zaslavskaya, "Challenges to Interaction between EAEU and EU," Administrative Consulting, no 11 (2017): 38-39.

32 Al.A. Gromyko, "Greater Europe: Internal and External Security Threats," Herald of the Russian Academy of Sciences 88 (2018): 185-191.

33 "Evraziiskii ekonomicheskii soiuz i Evrosoiuz: sotrudnichestvo, sosushchestvovanie ili konfrontatsiia," accessed October 21, 2019, https://eurasia.expert/evraziyskiy-ekonomicheskiy-soyuz-i-evrosoyuzsotrudnichestvo- sosushchestvovanie-ili-konfrontatsiya. 
impossible due to the ideological, military and political confrontation between the capitalist and socialist blocks.

As democratic reforms unfolded in the late 1980s, the Soviet Union took concrete steps to bring about a rapprochement of the Soviet Union and West European nations. Among other, the Soviet Union's leaders consented to abolishing the GDR and its subsequent unification with its capitalist counterpart into a united Germany, while Gorbachev proposed a "Common European Home." However, none of these initiatives helped integrate the USSR into a united Europe. Although the Soviet Union disintegrated in 1991, these moves still evoke controversy.

As V. Inozemtsev notes, the Russian Federation that succeeded it was not ready to join the EU because of its own wordview, ${ }^{34}$ and in the 1990 s it relied on the 1994 Agreement on Partnership and Cooperation to interact with the body. Meanwhile, Brussels continued to promote its own model of integration, with the EU at the center and Russia on the periphery. Nevertheless, their strategic partnership continued to thrive during the next decade, which resulted in adopting "roadmaps" and a "Partnership for modernization."

The years 2010s were a turning point in relations between Moscow and Brussels. The Ukrainian crisis and the EU's sanctions encouraged an eastward redirection in Russian foreign policy as it focused instead on Eurasian integration, and the concept of a Greater Eurasia began to replace that of a Greater Europe in the government's political discourse. Some scholars have noted that the same officials who had worked on the latter earlier on now turned their attention to the Greater Eurasia. As a result, the new model is similar to its predecessor in some respects. Furthermore, this development did not extinguish hopes for a Greater Europe, since the EAEU is open to cooperation and integration with similar groups in the West as well as in the East.

Any rapprochement between the two unions will only become possible the political barriers mounted by the EU in its relations with Russia and the EAEU are lowered. Brussels should stop perceiving the EAEU as a Russian project par excellence, aimed at reviving Moscow's hegemony in the post-Soviet space. Instead, its should realize that Eurasian integration in its current form is essential for promoting pan-European integration, i.e., the Greater Europe. The EAEU, in turn, should strengthen its international legal standing and the economies of its member nations, to stop merely following the EU's rules and standards, and move away from being its disciple towards establishing a level playing field with Brussels.

The idea of a Greater Europe has not lost its relevance. Despite some skepticism, French President Emmanuel Macron's declaration in August 2019 that he strongly advocates "a Europe stretching from Lisbon to Vladivostok," is evidence that a Greater Europe is still on the minds of Western Europe's leaders.

Рукопись поступила: 28 декабря 2019 г.

Submitted: 28 December 2019

\section{References}

Arbatova, N. "Cooperation or Integration? Russia and Greater Europe." Osteuropa 53, no. 9 (2003): $1492-1500$.

Busygina, I.M. Osnovy Bol'shoi Evropy. Moscow: Spetskniga Publ., 2014 (in Russian).

Gromyko, Al.A. "Greater Europe: Internal and External Security Threats." Herald of the Russian Academy of Sciences 88 (2018): 185-191 (in Russian).

${ }^{34}$ V. Inozemtsev, "Vozvrashchenie 'Bol'shikh strategii'," Russian International Affairs Council, accessed October 9, 2019, https://russiancouncil.ru/analytics-and-comments/analytics/vozvrashchenie-bolshikh-strategiy. 
Gurova, I. "Eastern Partnership: Trade Integration of the EU Target Countries." Mirovaya ekonomika $i$ mezhdunarodnye otnosheniya 62, no. 3 (2018): 86-97.

Hopf, T. Understandings of Russian Foreign Policy. Pennsylvania: Pennsylvania State University Press, 1999.

Il'in, E.Iu. "The concept of Greater Europe from Lisbon to Vladivostok: problems and perspectives," MGIMO Review of International Relations 4, no. 2 (2015): 77-85 (in Russian).

Kondrateva, N. "EU-EAEU Relations: Features of the Present Stage," Sovremennaya Evropa, no. 3 (2018): 60-70 (in Russian).

Kuznetsov, A. "Rethinking the concept of Greater Europe due to the Ukrainian crisis," International Affairs, no. 12 (2014): 6-17 (in Russian).

Lukin, A., and Novikov, D. "From Greater Europe to Greater Eurasia: What Brings the World a Fundamental Geopolitical Shift." Vostok. Afro-Aziatskie obshchestva: istoriia i sovremennost, no. 5 (2018): 60-76 (in Russian).

Mackinder, H.J. "The Geographical Pivot of History." The Geographical Journal 23, no. 4 (1904): 421-437.

Sakwa, R. "Looking for a Greater Europe: From Mutual Dependence to an International Regime." Communist and Post-Communist Studies 45, no. 3-4 (2012): 315-325.

Taras, R. Russian Identity in International Relations: Images, Perceptions, Misperceptions. London: Routledge, 2013.

Tsvyk, A.V. “ 'Greater Europe' or 'Greater Eurasia'? In Search of New Ideas for the Eurasian integration." RUDN Journal of Sociology 18, no. 2 (2018): 262-270 (in Russian).

Vinogradov, A.V. "Russia in Eurasia: between China and the West. Identity, Ideology and Geopolitics." Outlines of global transformations: politics, economics, law 12, no. 2 (2019): 228-246 (in Russian).

Zaslavskaya, N.G. "Challenges to Interaction between EAEU and EU." Administrative Consulting, no 11 (2017): 38-39 (in Russian).

\section{Библиографический список}

Бусыгина И.М. Основы Большой Европы. РСМД. М.: Спецкнига, 2014. 350 с.

Виноградов A.B. Россия в Евразии: между Китаем и Западом. Идентичность, идеология и геополитика // Контуры глобальных трансформаций: политика, экономика, право. 2019. Т. 12. № 2. С. 228-246.

Гурова И. Восточное партнерство: торговая интеграция “целевых" стран Евросоюза // Мировая экономика и международные отношения. 2018. Т. 62. № 3. С. 86-97.

Громыко Ал.А. Большая Европа. Идеи, реальность, перспективы. М.: Весь Мир; Ин-т Европы PAH, 2014. $704 \mathrm{c}$.

Заславская Н.Г. Проблемы взаимодействия ЕАЭС и ЕС // Управленческое консультирование. 2017. № 11. С. 38-39.

Ильин Е.Ю. Концепция Большой Европы от Лиссабона до Владивостока: проблемы и перспективы // Вестник МГИМО-Университета. 2015. № 2. С. 77-85.

Кондратьева Н. Отношения ЕС-ЕАЭС: особенности современного этапа // Современная Европа. 2018. № 3. C. 60-70.

Кузнецов А. Переосмысление концепции Большой Европы в связи с украинским кризисом // Международные отношения. 2014. № 12. С. 6-17.

Лукин А., Новиков Д. «От Большой Европы к Большой Евразии: что приносит миру фундаментальный геополитический сдвиг». Восток // Афро-азиатские общества: история и современность. 2018. № 5. С. 60-76.

Цвык А.В. «Большая Европа» или «Большая Евразия»? В поисках новых идей для евразийской интеграции» // Вестник Российского университета дружбы народов. Серия: Социология. 2018. T. 18. № 2. C. 262-270.

Arbatova N. Cooperation or Integration? Russia and Greater Europe // Osteuropa. 2003. T. 53. № 9. C. $1492-1500$.

Hopf T. Understandings of Russian Foreign Policy. Pennsylvania: Pennsylvania State University Press, 1999. $294 \mathrm{p}$.

Mackinder H.J. The Geographical Pivot of History // The Geographical Journal. 1904. Vol. 23. № 4. P. 421-437. 
Sakwa R. Looking for a Greater Europe: From Mutual Dependence to an International Regime // Communist and Post-Communist Studies. 2012. Vol. 45. № 3-4. P. 315-325.

Taras R. Russian Identity in International Relations: Images, Perceptions, Misperceptions. London: Routledge, 2013. 155 p.

\section{Информация об авторах / Information about the authors}

Цвык Анатолий Владимирович, кандидат исторических наук.

Курылев Константин Петрович, доктор исторических наук, профессор кафедры теории и истории международных отношений Российского университета дружбы народов
Anatoly V. Tsvyk, Kandidat Istoricheskikh Nauk [PhD. in History].

Konstantin P. Kurylev, Doktor Istoricheskikh Nauk [Dr. habil hist.], Professor at the Department of Theory and History of International Relations, RUDN University. 